\title{
Denationaliserad straffrätt - vilka utmaningar står för dörren? ${ }^{1}$
}

Af Petter Asp ${ }^{2}$

\begin{abstract}
Criminal law is in the middle of a process which can be described as denationalization, i.e. a process under which national criminal law is increasingly being influenced and affected by international norms of different kinds (general principles of international law, norms contained in treaties etc.) and where the norms are no longer created only by the national legislator. In this article the author tries to describe some of the challenges that we are facing due to this development.
\end{abstract}

\section{Inledning}

\subsection{Inledning}

Om jag blev ombedd att peka på de två faktorer som har påverkat straffrätten mest under de senaste decennierna skulle jag framhålla:

(1) den politisering av straffrätten som har skett (här väljer jag, med hänsyn till att det framstår som tveksamt om man kan tala om att politiseringen tilltar, att tala om detta närmast som en förändring som har inträffat snarare än som en pågående process), och

(2) den tilltagande internationaliseringen av straffrätten.

Med politisering avser jag det förhållandet att straffrätten har gått ifrån att vara ett område som från politisk synpunkt var ganska ljummet till att ha en relativt central politisk roll. ${ }^{3}$ Med internationaliseringen avser jag att straffrätten inte längre är en rent nationell angelägenhet utan istället utgör ett rättsområde som utsätts för ett tilltagande inflytande från internationellt håll, att straffrätten i allt större utsträckning konstitueras av eller påverkas av internationell rätt $i$ en eller annan mening. Fråga kan exempelvis vara om påverkan som härrör (i) från innehållet i den allmänna folkrätten, (ii) från mellanstatliga traktater av bilateral eller multila-

* Title in English: Denationalization of criminal law - what challenges are we facing? 
teral karaktär, härunder bl.a. Europakonventionen eller (iii) från EU-rätten. Härtill kommer också (iv) annan påverkan som sker genom andra typer av ickenationella normer eller institutioner (typexempel kan vara den påverkan som FATF eller GRECO har på den nationella rätten) liksom (v) annan mer löslig påverkan som sker genom att nationella jurister och beslutsfattare konfronteras med och tvingas förhålla sig till normer från andra rättsordningar (inspiration, ifrågasättande, eftertanke, utvärdering etc. som bygger på ett möte med utländsk eller internationell rätt $\mathrm{i}$ någon form).

Som framgår av rubriken kommer jag i denna uppsats att fokusera på de utmaningar som internationaliseringen innebär, även om dessa inte saknar kopplingar till det fenomen som kan kallas politiseringen.

\subsection{Ett terminologiskt skifte}

Med denna allmänna inledning given skulle jag vilja inleda mina reflektioner kring internationaliseringen med en terminologisk anmärkning och ett terminologiskt skifte.

Vi talar ofta om straffrättens (eller juridikens) internationalisering - det gjorde jag själv i föregående avsnitt. Inom ramen för ett från rättslig synpunkt internt ämnesöverskridande projekt (eller embryo till ett projekt) med inriktning just på frågor om globalisering och internationalisering (vid Stockholms universitet) har emellertid jag och mina kolleger frågat oss om det inte kan finnas skäl att tala om avnationalisering eller, för att ta en term som är mer direkt översättbar, denationalisering snarare än om internationalisering. ${ }^{4}$ Detta terminologiska skifte syftar närmast till att antyda att den största förändringen kanske inte ligger i vad vi kommer till (det internationella i någon mening) utan i vad vi sakta är på väg ifrån, nämligen en central och sedan länge fast förankrad utgångspunkt för rätten: nationalstaten.

Vi lämnar därmed mycket av det vi mer eller mindre har tagit som utgångspunkt för vår verksamhet. Jag tänker här på ganska basala saker som t.ex.:

- En grundläggande tanke på ett system som hänger samman och ett därmed sammankopplat naturligt koherenskrav (så länge man har en huvudsaklig normgivare är det ett rimligt krav att den åtminstone drar jämnt med sig själv)

- Ett någorlunda komplett rättssystem som har förfinats och utvecklats över tid (en väv som s.a.s. är så komplett att den ganska väl låter sig utfyllas i den mån det finns luckor) 
- En någorlunda enhetlig juridisk kultur (personer utbildade inom samma utbildningssystem, läsandes samma läroböcker, handböcker och artiklar, verksamma mot en fond bestående av ett och samma domstolssystem etc.)

- En någorlunda enhetlig förförståelse och världsbild (jfr med tiden när det bara fanns en eller två TV-kanaler)

- En utgångspunkt i att rätten hämtar sin legitimitet från de folkvalda (vilket åtminstone i praktiken förutsätter något slags närhet)

- En utgångspunkt vad gäller intern giltighet som åtminstone i grunddragen är lätt Kelsenianska (med underordnade normer som i grunden härleder sin giltighet från överordnade normer inom ramen för vad som kan betecknas som ett system).

Denna traditionella bild av rätten - som självfallet ska förstås som en idealtyp snarare som än en realistisk beskrivning - håller nu på att ersättas av en mer mångfacetterad och denationaliserad rätt.

Det finns flera skäl till denna utveckling. Bl.a. kan hänvisas till:

- skapandet av mellanstatliga och övernationella organisationer som bl.a. eller ibland t.o.m. i huvudsak ägnar sig åt normskapande verksamhet (jfr EU, FN, WTO osv.)

- problem som för sin lösning förutsätter samarbete mellan flera stater (jfr miljöproblem, problem med gränsöverskridande brottslighet, hanteringen av internet osv.)

- ökad mobilitet på olika sätt (både vad gäller personer, information, varor osv.)

- ett ökat intresse för att finna och fastställa vissa grundläggande normer som ska gälla oberoende av nationsgränser.

Poängen med att i detta sammanhang tala om denationalisering (istället för om internationalisering) är att rikta fokus mindre mot vad som nu släpps in på arenan (det internationella) utan snarare mot det förhållandet att det nationella - som i mångt och mycket har stått för juridikens stabilitet - utmanas på en lång rad sätt. Självfallet kan man invända att internationalisering och denationalisering är två sidor av samma mynt, men jag tror att det kan ha viss betydelse för den process vi befinner oss $i$ att vi identifierar vad det är som innebär de stora och revolutionerande förändringarna. 


\subsection{Försvar för ett kritiskt perspektiv}

Denationaliseringen är naturligtvis på många sätt fascinerande och intressant. Det låter sig bl.a. sägas att denationaliseringen är befriande eller öppnande såtillvida att den innebär att nationella mönster och käpphästar inte längre gör sig gällande med samma styrka som tidigare. Denationaliseringen gör det möjligt att argumentera i nya banor och att åberopa »nya« auktoriteter; det finns »nya« normer att åberopa för att undergräva giltigheten av eller modifiera innebörden av de gamla och nya rättsliga strukturer skapar utrymme för nya argumentationsmönster. Utvecklingen är naturligen också mycket dynamisk: när man tänker på nya sätt och rycker i bestämmelser både här och där sker det, som Per Henrik Lindblom skriver, inte sällan saker också på andra ställen i systemet.

Låt mig inleda med att säga att också jag i grunden hör till de hänfördas skara. Utvecklingen är fascinerande och intressant att följa.

Samtidigt kan inte förnekas att utvecklingen också ställer rätten inför påtagliga utmaningar och problem och det är i första hand på dessa jag ska fokusera i det följande. Jag ber om ursäkt för detta (det medges villigt) ganska trista anslag inte minst som det anförande som denna text bygger på hölls vid Svenska kriminalistföreningens 100-års jubileum kan anslaget tyckas oförlåtligt - men det står enligt min mening klart att det är betydligt viktigare att tala om problemen och svårigheterna än att ge uttryck för storögd fascination.

Jag vill emellertid särskilt framhålla att mitt fokus på problem och svårigheter inte ska ses som ett uttryck för en allmänt denationaliseringsfientlig hållning.

Vad vi upplever är i grund och botten något positivt - inte minst såtillvida att internationella normer om mänskliga rättigheter får en allt tydligare och allt säkrare position - men det hindrar förstås inte att det också finns avigsidor.

Särskilt när det gäller frågor kopplade till internationalisering/denationalisering finns emellertid ibland en tendens till svartvithet där man tenderar att hamna i något av facken »med« eller »mot«. Det finns säkerligen flera skäl till denna tendens. Ett av dem kan vara att denationaliseringen inte sällan har inneburit en möjlighet att göra upp med nationella egenheter och särlösningar som, för att uttrycka sig försiktigt, inte har varit populära hos alla (jfr t.ex. debatten om skattetilläggen) och det är då naturligt att också försök till nyansering kan uppfattas som motstånd. Ett annat skäl till svartvitheten kan vara att kritiska synpunkter inte sällan gäller den internationella normgivningens kvalitet och förutsättningar och här kommer den omständigheten in att den internationella normgivningen nog får sägas vara särskilt svårstyrd och skriver sina normer med ganska trubbiga instrument. Den som problematiserar och kritiserar utvecklingen kan i en sådan 
kontext framstå som en nej-sägare: det finns ju i realiteten inget självklart alternativ till att acceptera de nya premisserna.

\subsection{Denationalisering på olika nivåer}

Innan vi övergår till att se på några av de utmaningar som denationaliseringen innebär kan det finnas skäl att säga några ord om att betydelsen av denationaliseringen kan te sig väsentligt olika beroende på i vilket perspektiv man ser saken. Uppenbart är förstås att graden av denationalisering kan variera beroende på vilket rättsområde vi talar om - och härvidlag har straffrätten varit ett av de områden som tydligast varit knutna till nationalstaten. Det kan emellertid också vara av vikt att framhålla att denationaliseringen har olika betydelse för olika aktörer inom rättsordningen.

Tydligast blir förändringen tveklöst om man anlägger ett lagstiftarperspektiv. En mycket stor del av lagstiftningsverksamheten handlar numera i praktiken om att förhandla, hantera och genomföra olika typer av internationella instrument. Det gäller framför allt sådana instrument som är antagna inom EU, men även internationella överenskommelser som framförhandlas i andra fora. I sammanhanget kan noteras att ett skäl till att denationaliseringen föranleder viss oro är att det internationella arbetet tar så mycket av tid och kraft att det nödvändiga »rättsvårdande« arbetet (i form av översyner som syftar till puts snarare än reformer) blir lidande.

Om man istället anlägger ett domarperspektiv blir bilden - åtminstone på det straffrättsliga området - påtagligt annorlunda. Med undantag för enstaka fall, som dyker upp med mer eller mindre ojämna mellanrum, är straffrättskipningen i allt väsentligt fortfarande nationell. Visst förekommer enstaka fall där EU-rätten påverkar utfallet $\mathrm{i}$ våra processer och visst förekommer det att Europakonventionen blir av betydelse (det gäller framför allt straffprocessuella frågor), men det är alldeles tydligt att detta inte förmår rubba helhetsbilden: från rättslig synpunkt är straffrätten i domstol som huvudregel nationell och det internationella inslaget består som huvudregel i att de nationella reglerna har en internationell bakgrund och/eller hänvisar till internationella normer. Detta beror naturligtvis till stor del på att internationella straffrättsliga överenskommelser är avsedda att genomföras på nationell nivå och i princip inte heller självständigt kan ligga till grund för straffansvar - det sagda gäller såväl sedvanliga internationella konventioner som rambeslut (pre-Lissabon) och direktiv (framför allt post-Lissabon) inom EU. 


\section{2. Åtta utmaningar}

Med det ovan sagda som ett slags utgångspunkt ska jag nu övergå till att diskutera några av de utmaningar som denationaliseringsprocessen ställer oss inför. Jag kommer i denna del att använda EU-samarbetet som exempel om inte annat sägs (främst därför att det för svensk straffrätts del är den ojämförligt viktigaste faktorn i den pågående denationaliseringsprocessen). De utmaningar jag tar upp är delvis överlappande - verkligheten låter sig inte alltid sorteras in i väl avgränsade burkar - vilket man bör ha i åtanke när man läser texten.

\section{Utmaning $\mathrm{nr}$ 1: Att styra kriminalpolitiken}

En första utmaning vi står inför är att hantera den minskade styrbarhet som denationaliseringen innebär. På nationell nivå har framför allt regeringen - på olika sätt beroende på statsskickets utformning - möjlighet att styra rättsutvecklingen och därigenom driva en kriminalpolitisk linje, låt vara att denna möjlighet kanske inte alltid utnyttjas till fullo. Man kan säga att makten i viss utsträckning är koncentrerad. För svensk rätts del återspeglas denna möjlighet till styrning direkt $\mathrm{i}$ regeringsformen 1 kap. $6 \S$ : regeringen styr riket. Att på detta sätt styra en verksamhet blir av naturliga skäl väsentligt svårare när besluten $i$ allt väsentligt värks fram genom en internationell förhandlingsprocess.

Bildligt talat har vi gått från en situation där kriminalpolitiken styrs av en person som faktiskt sitter vid ratten (regeringen) till en situation där bilen ska styras av ett kollektiv. När flera sliter i ratten samtidigt påverkar detta naturligtvis möjligheterna att hålla en rät kurs. Under förutsättning att man ser det som angeläget att bedriva en sammanhållen och rationell kriminalpolitik är detta följaktligen något som måste hanteras. Man kan uttrycka det så att de nya normgivningsprocesserna i sig skapar kriminalpolitiska utmaningar.

Det kan i detta sammanhang noteras att den övergång från beslut medelst enhällighet till majoritetsbeslut som på det straffrättsliga området skedde genom Lissabonfördragets ikraftträdande, i detta perspektiv kan ses som något mycket positivt. Att övergå till majoritetsbeslut är i detta avseende ett sätt att göra det möjligt för någon att sätta någon vid ratten.

\section{Utmaning nr 2: Att hantera den förändrade beslutsmiljön}

En andra utmaning ligger däri att denationaliseringen innebär att besluten flyttas upp ytterligare en nivå mätt i politisk temperatur. Normgivningen på nationell nivå är en fråga om rikspolitik, och det kan förvisso vara en kontext $\mathrm{i}$ vilken trycket kan bli stort, men det torde stå alldeles klart att flytten upp till internationell högpolitisk nivå, med en tydlig koppling till diplomatiska kanaler, riskerar bå- 
de att göra trycket ännu större och att skapa ett klimat där symbol och fasad är viktigare än reella framsteg. Att vara nej-sägare i ett sammanhang där en viss åtgärd internationellt framstår som (politiskt) angelägen är helt enkelt inte alltid så lätt.

Om man vad gäller det politiska livet gör ett försök att särskilja ett rent politiskt element och ett mer normgivande och förvaltande element - att en sådan distinktion kräver förenklingar och är dömd att vara trubbig hindrar inte att den kan göras - kan man säga att flytten från riksnivå till europeisk nivå medför att det politiska elementet vinner i styrka på bekostnad av det normgivande och förvaltande.

\section{Utmaning nr 3: Att åtgärda den bristande demokratiska förankringen}

En tredje utmaning gäller att åtgärda beslutens bristande demokratiska förankring. Om man inleder med att analysera situationen från formell synpunkt kan visserligen konstateras att Europaparlamentet efter Lissabonfördragets ikraftträdande blivit medbeslutande vad gäller straffrättsliga instrument. Samtidigt kan ifrågasättas i vilken utsträckning Europaparlamentet med hänsyn till bl.a. valdeltagandet, parlamentets storlek och representativitet samt avståndet till medborgarna verkligen kan anses garantera en tillräcklig demokratisk förankring.

Minst lika viktigt som de mer formellt inriktade bristerna är emellertid den bristande reella demokratiska förankringen och de bristande möjligheterna till ett reellt och informerat inflytande över den politiska processen. Det är helt enkelt mycket svårt för medborgarna att informera sig om pågående normgivningsarbete och än svårare att initiera en debatt och diskussion om olika frågor som har förutsättningar att verkligen betyda något. Av betydelse i detta sammanhang är bl.a. geografiska avstånd, språkliga svårigheter (bara i EU finns 23 officiella språk) och avsaknaden av gemensamma fora för diskussion och debatt. Väldigt enkelt uttryckt förutsätter en meningsfull debatt att en kritisk massa av medborgare ges en arena där saker kan diskuteras. Självfallet finns det begränsningar också på nationell nivå - alla har inte tillgång till DN debatt - men den gemensamma arena för information och debatt (i form av TV, radio, tidningar och nätsajter) som ändå finns på nationell nivå saknar i praktiken nästan helt motsvarighet på internationell nivå.

\section{Utmaning $n r$ 4: Att skapa rimlig kvalitet i förarbetsprocessen}

En fjärde utmaning gäller möjligheterna att upprätthålla kvalitet $i$ förarbetsprocesserna. Här kan krasst konstateras att i relation till svenska förhållanden (liks- 
om till nordiska förhållanden i övrigt) så måste förarbetena till normgivningen på EU-nivå anses ligga långt efter de svenska motsvarigheterna.

Antagligen kan man argumentera för att detta problem förutsätter ett visst utgångsläge dvs. att man på nationell nivå har en process som på ett bättre sätt tillförsäkrar kvalitet i normgivningen. Anlägger man ett svenskt (eller nordiskt) perspektiv kan emellertid - och det gäller oberoende av hur man ställer sig till förarbetstrogenhet i rättstillämpningen eller vad man tycker om kvalitetsutvecklingen när det gäller förarbetena under de senaste 40 åren - lugnt konstateras att också förarbetena på 2010-talet håller väsentligt högre kvalitet än motsvarande texter (om det finns några) inom EU och det gäller såväl valet av lösningar eller åtgärder (allmänmotivering) som det rättsliga detaljarbetet (lagstiftningens utformning och specialmotivering). Likaså gäller att remissförfarandet på internationell nivå generellt sett är underutvecklat (jfr föregående punkt) och alldeles oberoende av vilka ambitioner man har, och vilka åtgärder man vidtar för att åtgärda problemet, kommer det att vara fortsatt svårhanterat i en internationell miljö.

\section{Utmaning $n r$ 5: Att hantera de försämrade förutsättningarna för normgivnings- arbetet}

Utmaningarna vad gäller kvalitet orsakas inte bara av bristande kvalitet vad gäller "underarbetet«, utan också av nya förutsättningar på ett mer allmänt plan.

En viktig sådan är att lejonparten av normgivningsarbetet sker på ett språk som inte utgör deltagarnas modersmål eller bedrivs med hjälp av tolk. När det gäller en materia (rätten, juridiken) som i stor utsträckning är språk, är det närmast givet att detta påverkar kvaliteten i negativ riktning. Tillspetsat uttryckt kan sägas att människor - i detta sammanhang - bokstavligt talat blir dummare när de verkar på ett språk som inte är deras modersmål.

Detsamma kan sägas om det förhållandet att de inblandade heller inte har samma förförståelse av den materia som ska hanteras. Här kan man börja med så enkla saker som att företrädare för olika stater har gått olika juristutbildningar och läst olika läroböcker (här finns naturligtvis skillnader också inom stater, men det torde kunna förutsättas att likheterna i vart fall är större än mellan stater). Detta betyder helt enkelt att man går in i diskussionen med divergerande förförståelser, vilket i sin tur försvårar kommunikation och förståelse på olika sätt.

Likaså finns det skillnader i sättet att angripa juridiska frågor. Redan inom norden kan t.ex. skönjas en viss skiljelinje mellan västnordisk pragmatism (Danmark och Norge) och östnordisk teori- och systemorientering (Finland och Sverige). Skillnaderna blir mer än skönjbara om man jämför angreppssättet i Tyskland och Storbritannien. Även om dylika indelningar kräver åtskilliga reservationer 
och självfallet inte är annat än generaliseringar som inte går att överföra till personnivå så tror jag att de fångar något som är väsentligt att uppmärksamma. Det år inte endast språket som påverkar vår kommunikation, utan också våra strukturer och »bilder« av det som är föremålet för vår diskussion. I olika rättsliga kulturer tänker man i olika kategorier och på olika sätt och att skapa normer av god kvalitet $\mathrm{i}$ ett normgivningsarbete som ligger i skärningspunkten mellan olika rättsliga kulturer är naturligtvis besvärligt.

Det sagda implicerar naturligtvis inte att mötet med »det andra« inte har några positiva sidor - det är lätt att peka på sådana - utan syftar endast till att lyfta fram avigsidorna.

\section{Utmaning $n r$ 6: Att hantera den polycentriska normgivningen och upprätthålla idén om koherens}

En ytterligare utmaning ligger i den tendens till polycentrisk normgivning som närmast automatiskt ligger inbakad i denationaliseringen. Vi kan här se hur vi å ena sidan hamnar i en situation där flera normgivare utfärdar normer som gäller i relation till ett och samma rättssystem. I svensk rätt tillämpas normer som kommer till i Stockholm, Bryssel, Strasbourg och New York bara för att ge några exempel. Detta kan ytterst leda till direkta konflikter av både logisk och axiologisk karaktär, men också till mindre allvarliga problem i normgivningsarbetet (ett exempel kan vara att det utarbetas två internationella instrument avseende samma område som i det stora hela är avsedda att reglera samma sak, men som innehåller skillnader i detaljer; dylik dubbelreglering gör det inte sällan svårt att finna en vettig regleringsform på nationell nivå). ${ }^{5}$

$\AA$ den andra sidan kommer också normer som utfärdas av en normgivare att bli tillämpliga i flera olika rättssystem; ett tydligt exempel på detta är samarbetet inom EU. Det betyder att samma norm ska kunna fungera i delvis olika kontexter.

Detta innebär naturligtvis metodologiska utmaningar på flera plan. Bl.a. måste det finnas en beredskap för att hantera de frågor som uppstår när normerna kolliderar - det kan nästan förutsättas att intresset för hanteringsnormer kommer att öka framgent - liksom det i ökad utsträckning uppstår frågor om hur man ska passa in normer som beslutats i en annan kontext i ett givet system (även om man kan hävda att de nationella systemen egentligen inte finns som fristående entiteter längre är det alldeles tydligt att vi i realiteten fortfarande lever med nationella rättssystem som på olika sätt och i olika delar öppnas för inflytande utifrån).

Än viktigare än de konflikthanteringsproblem som uppstår är de normativa utmaningar vi står inför. Om, dvs. under förutsättning att, vi bryr oss om intressen som koherens och likabehandling - och allt tyder på att vi gör det - finns det 
all anledning att vara bekymrad över denna rättens framväxande fragmentisering. Som rättsvetare har man naturligtvis all anledning att påpeka att rätten långt ifrån alltid är det normativt sammanhängande system som vi så ofta förutsätter, men det hindrar förstås inte att det utgör ett problem om samhällets mest auktoritativa normsystem, avsett att hantera allvarliga konflikter, talar med kluven tunga. Tanken på koherens och enhet är inte bara en föreställning om något slags enhet som man kan både ha och mista - utan något som i grunden går att återföra på viktiga värden som rättvisa och likabehandling. Man kan naturligtvis differentiera så mycket som man önskar inom juridiken/rätten, men när man väl har bestämt sig för vad som utgör relevanta kriterier och värden är likabehandling utifrån dessa $\mathrm{i}$ grunden något önskvärt. Det är med denna utgångspunkt också viktigt att rätten är normativt någorlunda koherent; i annat fall blir alla tankar på rättvisa och likabehandling formella. Inte minst på straffrättens område där normerna på ett särskilt tydligt sätt är avsedda att utgöra axiologiska måttstockar är problemet reellt. Man kan i sammanhanget också peka på att straffrätten, delvis därför att den förutsätts hänga samman, har särskilt utpräglad systematisk karaktär där normkonflikter kan skapa särskilt stora svårigheter.

Paradoxalt nog kan utvecklingen här sägas gå i två diametralt motsatta riktningar. Å ena sidan skapar polycentrin risker för olika typer av konflikter som gör oss benägna att tona ned intresset av koherens och sammanhang. Vi börjar så att säga så smått ge upp tanken på övergripande koherens. A andra sidan går vi i riktning mot att utvidga enheten för att bedöma enhetlighet allt mer. För 20 år sedan hade det knappast kunnat ses som ett problem om de straffrättsliga reglerna $i$ Sverige och Rumänien skiljer sig åt. Idag är det emellertid alls inte orimligt att ställa frågan om väsentliga normmässiga skillnader mellan de nämnda staterna utgör ett problem. Enheten för bedömning av det allmänna kravet på likabehandling tenderar helt enkelt att vidgas. Inom EU framförs t.ex. ofta som ett skäl för harmonisering att det är ohållbart om reglerna i de olika medlemsstaterna ser olika ut. Detta kan göras både därför att vi faktiskt uppfattar en gemenskap (inom vilken likhet bör råda) och av det skälet att likhet kan vara önskvärd av mer instrumentella skäl (t.ex. för att inte snedvrida konkurrensen eller för att vi av symboliska skäl vill skapa en känsla av gemenskap).

I sammanhanget bör noteras att koherenskravet inte bara är av intresse från materiella utgångspunkter; det är också av intresse som en viktig ingrediens $i$ ett maktdelningsperspektiv. Lagstiftaren har i grunden mycket stor frihet att utforma rätten så som han eller hon önskar och i detta avseende bidrar kravet på koherens med en central begränsning: denne bör dra jämt åtminstone med sig själv. En makthavare som förklarar sig vara likgiltig inför kravet på koherens skapar 
därigenom ett betydande utrymme för godtycke. Om man kritiskt frågar en makthavare hur två olika beslut går ihop, vill man inte mötas av svaret: »inte alls, men vad gör väl det«.

\section{Utmaning nr 7: Att hantera rollen som sido- eller stöddisciplin}

En ytterligare utmaning är att hantera rollen som sidodisciplin. Straffrätten är på nationell nivå huvudsakligen ett ämnesområde som behandlas som ett mål i sig. Inom EU är situationen en helt annan. Fokus är bara delvis på straffrätten och genom artikel 83.2 EUF har straffrätten uttryckligen givits rollen som ett slags genomförandemekanism. Man kan uttrycka det så att perspektivet är fackdepartementets (hur säkrar vi bäst efterlevnaden av för oss viktiga regler?) snarare än justitiedepartementets (hur vårdar vi straffrätten?).

Självfallet är straffrätten i mångt och mycket ett medel för att säkra efterlevnad av (andra) regler, men straffrätten är inte bara detta, utan också ett sätt att hantera riskerna med statlig maktutövning. Det kan inte utan fog hävdas att perspektivbytet innebär en risk för att perspektivet blir alltför instrumentellt och ensidigt härvidlag (erfarenheten från nationell nivå talar för att straffrätten, när den endast ses som ett medel, riskerar att missbrukas).

\section{Utmaning $n r$ 8: Att hantera framstegsoptimismen}

Avslutningsvis vill jag rasta en gammal käpphäst. En viktig utmaning på det straffrättsliga området är att hitta vägar att hantera vad man skulle kunna kalla framstegsoptimismen. Straffrätten är i mångt och mycket en ganska stabil bas i rättsordningen. Visst sker reformer och visst sker utveckling, men i grund och botten är systemet avsett att tillhandahålla relativt stabila och grundläggande normer. Inte minst med beaktande av att det straffrättsliga EU-arbetet - åtminstone när det gäller harmonisering av den materiella straffrätten - tar sin utgångspunkt $\mathrm{i}$ existerande och någorlunda kompletta nationella straffsystem bör det stå klart att det är befogat med en viss försiktighet vad gäller bedömningen av hur mycket mervärde som egentligen står att finna.

Detta kolliderar i viss utsträckning med synsättet inom EU där tanken på ett slags framåtrörelse är påtaglig. Nya instrument ska antas och institutioner skapas för att man ska nå ytterligare ett steg framåt på vägen mot ett ännu odefinierat mål.

Om man till detta lägger att framsteg på det straffrättsliga området i regel uppfattas som detsamma som utvidgad kriminalisering och ökad repression finns det anledning att vara orolig för att alltför stora framsteg kommer att göras framöver. Ett rimligt perspektiv för en normgivare på det straffrättsliga området bör vara 
någorlunda regelbunden »rättsvård« och översyn - inte en strävan efter ständiga framsteg. Sammantaget framstår det som ganska tydligt att en sådan mer förvaltande hållning inte riktigt går att förena med det synsätt som - åtminstone hittills - har dominerat inom EU.

\section{Avslutning}

Jag har ovan försökt lista de kanske viktigaste utmaningarna som straffrätten står inför som en följd av denationaliseringen. Det är möjligt att jag i vissa delar överdriver riskerna. Det är möjligt att jag i andra delar uttrycker mig alltför försiktigt. Jag tror emellertid att det är viktigt - viktigare än att nyanserna i alla delar blir riktiga - att vi hela tiden påminner oss om vad vi håller på med och försöker se oss själva utifrån. I annat fall är risken stor att denationaliseringen innebär en övergång till en normgivningsprocess där vi reaktivt arbetar med de initiativ som sköljer över oss istället för att faktiskt göra ett allvarligt menat försök att styra över vår straffrättsliga framtid och värna möjligheterna till en sammanhållen, rationell och human kriminalpolitik.

\section{Noter}

1. Ett tack till Dan Helenius för synspunkter på ett utkast till denna artikel.

2. Professor i straffrätt vid Stockholms universitet och innehavare av Torsten och Ragnar Söderbergs professur i rättsvetenskap

3. Se t.ex. Victor i Varning för straff (utg. av Victor) 1995. Litet paradoxalt är att det, samtidigt som kriminalpolitiken framstår som en viktig politisk fråga, är svårt att säga annat än att de flesta politiska partier spelar på ungefär samma planhalva, dvs. det är svårt att säga att det mellan de dominerande partierna finns påtagliga skillnader vad gäller den grundläggande straffrättspolitiken. Kanske kan man också i den ekonomiska krisens spår skönja ett något svalare intresse för straffrättspolitiken.

4. De övriga deltagarna i denna diskussion har varit Antonina Bakardjieva Engelbrekt, Jonas Ebbesson och Mauro Zamboni.

5. Ett färskt exempel kan hämtas från dubbelregleringen avseende förebyggande av terrorism (där såväl Europarådet som EU kommit med instrument att hantera); jfr Ds 2009:17 s. 53 ff. och $122 \mathrm{f}$. 